\section{Nauplius}

The Journal of The

Brazilian Crustacean Society

e-ISSN 2358-2936

www.scielo.br/nau www.crustacea.org.br
This article is part of the special series offered by the Brazilian Crustacean Society

in honor to Ludwig Buckup in recognition of

his dedication and contributions to the

development of Carcinology

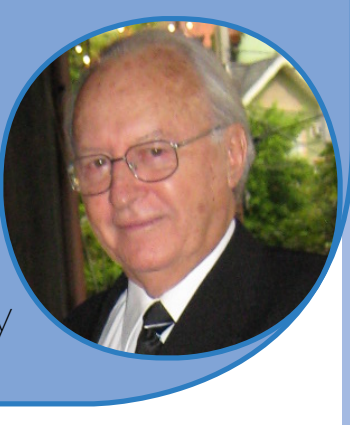

Original Article

\title{
Population structure of two freshwater amphipods (Crustacea: Peracarida: Hyalellidae) from southern Brazil
}

\author{
Aline Vasum Ozga ${ }^{1}$ orcid.org/0000-0001-7454-5503 \\ Vanessa da Silva de Castro ${ }^{2}$ \\ Daniela da Silva Castiglioni ${ }^{2}$ orcid.org/0000-0002-3041-5608
}
1 Programa de Pós-Graduação em Biodiversidade Animal, Centro de Ciências Naturais e Exatas, Universidade Federal de Santa Maria. Santa Maria, Rio Grande do Sul, Brasil. AVO E-mail: alinevasum@yahoo.com.br
2 Laboratório de Zoologia e Ecologia, Campus de Palmeira das Missões, Universidade Federal de Santa Maria. Palmeira das Missões, Rio Grande do Sul, Brasil. vsC E-mail: assenan_vany@hotmail.com DSC E-mail: danielacastiglioni@yahoo.com.br

ZOOBANK: http://zoobank.org/urn:lsid:zoobank.org:pub:AB672A72-B517-4DF9B28F-35A48473605C

\section{Abstract}

Two recently described amphipods species from southern Brazil, Hyalella georginae Streck and Castiglioni, 2017 and Hyalella gauchensis Streck and Castiglioni, 2017, had their population structures characterized by sex, females' ovigerous condition, cephalothorax length $(\mathrm{mm})$, size-class frequency distribution, sex-ratio, reproductive period, and recruitment. The specimens were collected with a dip net from a stream source (H. georginae) and from a

CORRESPONDING AUTHOR Daniela da Silva Castiglioni danielacastiglioni@yahoo.com.br

SUBMITTED 10 October 2017 ACCEPTED 23 August 2018 PUBLISHED 03 December 2018

\section{Guest Editors}

Alessandra A. de Pádua Bueno and Sandro Santos

DOI 10.1590/2358-2936e2018025 water reservoir (H.gauchensis) in the Palmeira das Missões municipality, state of Rio Grande do Sul, Brazil, from August 2012 to July 2013 (12 months). Both species showed a bimodal frequency distribution for total and seasonal size classes, with males larger than females. Overall, the sex ratio favored females when analyzed monthly and seasonally. Ovigerous females were recorded throughout the year, with higher frequency in spring (H.georginae) and summer (H.gauchensis), characterizing a seasonal reproduction. Both species showed continuous recruitment, with greater intensity in the spring. The population structure of these two Hyalella species had similar features, 
showing continuous recruitment and seasonal reproduction related to their life-history strategies, which promote adaptations to their habitat.

\section{KEY WORDS}

body size, Hyalella, recruitment, reproductive period, sex ratio.

\section{INTRODUCTION}

The study of population structure provides information about the ecological structure of natural populations (Hutchinson, 1981; Santos et al., 1995) such as its stability, productivity, and function within the trophic chain (Cooper, 1965). Understanding the dynamics of a population is useful for providing species conservation measures. Since growth, birth, reproduction, and mortality rates can be inferred, it is possible to predict if a population is expanding or declining to extinction (Cooper, 1965; Muskó, 1992). Population structure of amphipods has been studied through the analysis of density, size and age class distribution, sex-ratio, recruitment, and growth (Guerao, 2003; Appadoo and Myers, 2004; Kevrekidis, 2004, 2005; Subida et al., 2005; Castiglioni and Bond-Buckup, 2008a).

The genus Hyalella Smith, 1874 is distributed in the Nearctic and Neotropical biogeographic regions; it is endemic from the Americas, and its species have a restricted distribution (Bousfield, 1996). The genus includes approximately 72 species (Baldinger, 2004; Colla and César, 2015; Streck et al., 2017; Bastos-Pereira et al., 2018.). Hyalella is found in a variety of freshwater environments, attached to aquatic macrophytes, swimming in the water column, or buried in the sediment (Kruschwiyz, 1978; Wellborn, 1995; Grosso and Peralta, 1999). Depending on the species, Hyalella has herbivorous, carnivorous, omnivorous, or detritivore feeding habits (Cooper, 1965, Witt and Hebert, 2000; Vainola et al., 2008). Individuals of this genus also act as important links in the transfer of matter and energy in their ecosystems (Moore, 1981; Casset et al., 2011), being the prey of animals such as fishes and birds (Musko, 1992; Casset et al., 2011).

Information concerning ecological features of freshwater crustaceans are scarce, especially those with the order Amphipoda. In the last few years, understanding of American's Hyalella has risen with an increasing number of taxonomic publications, indicating that there is still a large number of species unknown to science (González and Watling, 2002a, 2002b, 2003a, 2003b; Baldinger, 2004; Pereira, 2004; González et al., 2006; Cardoso et al., 2011; Bueno et al., 2013; Rodrigues et al., 2014; Cardoso et al., 2014; Colla and César, 2015). In Brazil, most studies of Hyalella concern new species descriptions (BastosPereira and Bueno, 2013; Bueno et al., 2013; Rodrigues et al., 2014; Cardoso et al., 2014; Bueno et al., 2014; Streck et al., 2017), however, knowledge on their life cycles, population biology e reproductive biology are limited by the studies of Castiglioni and Bond-Buckup (2008a) (Hyalella castroi González, Bond-Buckup and Araujo, 2006 and Hyalella pleoacuta González, Bond-Buckup and Araujo, 2006), Castiglioni et al. (2016) (Hyalella bonariensis Bond-Buckup, Araujo and Santos, 2008) and Ozga and Castiglioni (2017) (Hyalella gauchensis Streck and Castiglioni, 2017 and Hyalella georginae Streck and Castiglioni, 2017). Most of the remaining studies published on population, reproductive, systematic, and taxonomic aspects of Hyalella species were performed with the North American species H. azteca (Cooper, 1965; Wellborn, 1994; Grosso and Peralta, 1999; Wellborn et al., 2005).

The aim of this study was to increase the knowledge on the population ecology of Brazilian Hyalella species. To achieve this aim we made estimates of body size, size-class frequency distribution, sex-ratio, reproductive period, and recruitment of Hyalella georginae and Hyalella gauchensis. Species were collected from Palmeira das Missões municipality, in the northeast region of state of Rio Grande do Sul, Brazil. The species studied in this work were described recently by Streck et al. (2017).

\section{Materials and Methods}

Study sites. To study the population structure, individuals were collected monthly from August 2012 
until July 2013 (spring: September to November; summer: December to February; fall: March to May; winter: June to August), at "Sítio Taqui" in Palmeira das Missões municipality, state of Rio Grande do Sul (275' $56^{\prime \prime}$ S, 5318' 50"W). Hyalella georginae was sampled from a stream source, while $H$. gauchensis was sampled from a water reservoir. Palmeira das Missões' county is located in the Brazilian southern region, at the Rio Grande do Sul's North Plateau, and it is of great importance to the state's agriculture and farming. The state of Rio Grande do Sul has a climate classified as temperate Cfa according to the classification of KöppenGeiger (Peel et al., 2007) and is characterized as mild mesothermic, experiencing periods of drought during spring and summer (IBGE, 2013). The monthly sampling was taken at two sites. Site 1 (S1) consisted of a headwater shaded by small trees and surrounded by Gramineae and Pteridophytae. Although macrophytes of the genus Salvinia were present in the waterbody, $H$. georginae was only found and collected in the sediment. Site 2 (S2) was a shallow water reservoir $(\approx 30 \mathrm{~cm})$ with a large amount of aquatic Salvinia, which was used as shelter by $H$. gauchensis. At Site 2 was observed fishes and frogs that may be predators of Hyalella The distance between Site 1 and Site 2 is approximately 20 meters.

Sampling of Hyalella individuals. At each site, macrophytes and sediment were collected with a 250 $\mu \mathrm{m}$ mesh dip net during $20 \mathrm{~min}$, placed into plastic bags, and taken to the laboratory. In the field, ovigerous females (with eggs or juveniles in the marsupium) and couples in precopulatory behavior were separated individually into microtubes containing $70 \%$ ethanol.

In the laboratory, macrophytes and sediment were sieved ( $0.177 \mathrm{~mm}$ mesh) and washed in running water in order to retain the amphipods.

Hyalella georginae and H. gauchensis were grouped into four categories: juveniles - individuals with undeveloped secondary sexual character; males individuals with a well-developed gnathopod 2; females - individuals with oostegites and a small gnathopod 2; and ovigerous females - females carrying eggs or juveniles in the marsupium (Borowsky, 1991; Castiglioni and Bond-Buckup, 2008a).

All specimens were measured (cephalothorax length, CL in $\mathrm{mm}$ ) on the ocular micrometer of a stereomicroscope. The CL was taken from the anterior margin of the rostrum to the posterior margin of the cephalothorax. According to Castiglioni and BondBuckup (2008a), the CL is correlated with total body length; hence, this measure may represent the actual body size of Hyalella individuals.

Data analyses. The minimum, mean, and maximum CL values of males and females were estimated to each species. The mean sizes are given with their standard deviations. The means were compared between sexes and between species using the $t$ test $(\alpha=0.05)$ (Zar, 1996).

To compare the temporal variation of the population age-frequency distribution, we estimated total and seasonal frequency distributions of male and female size classes for each species population. We also analyzed seasonality in the species recruitment processes. The class ranges were determined through $1 / 4$ of the average standard deviation of the CL of sampled individuals (Markus, 1971). Normality of frequency distributions were analyzed through the Shapiro-Wilk test $(\alpha=0.05)$ (Zar, 1996).

The sex ratio (males:females) was calculated. The total, monthly, seasonal, and size-class (CL) sex proportions were expressed as the total number of males divided by the total number of females. The Chi-Square test $\left(\chi^{2}\right)$ with a significance level of 5\% (Zar, 1996), was used to verify if the sex-ratio followed the 1:1 ratio.

The frequency of ovigerous females in relation to that of adult females of each species was estimated in order to analyze the seasonal and monthly reproductive period. The proportion of ovigerous females was compared between months and seasons using the multinomial proportions test (MANAP; $\alpha=0.05$ ) (Curiand Moraes, 1981). Those $H$. georginae females with $C L>0.40 \mathrm{~mm}$ and $H$. gauchensis with $\mathrm{CL}>0.35 \mathrm{~mm}$ were considered adult females.

For the recruitment analyses, juvenile proportions were compared between months using the multinomial proportion test (MANAP; $\alpha=0.05$ ) (Curi and Moraes, 1981).

\section{ResULTS}

A total of 2,708 specimens of $H$. georginae were collected; 1,117 males, 1,247 females (213 ovigerous females), and 344 juveniles (Tab. 1) sampled from a stream source. Hyalella gauchensis showed 18,953 individuals; 6,403 males, 6,706 females (1,488 ovigerous females), and 5,844 juveniles (Tab. 2) sampled from a 
Table 1. Number of specimens sampled monthly for a year, monthly sex ratio and goodness of fit analysis $\left(\chi^{2}\right)$ of Hyalella georginae, Palmeira das Missões, state of Rio Grande do Sul, Brazil.

\begin{tabular}{|c|c|c|c|c|c|c|c|}
\hline & Males & Females & Ovigerous Females & Juveniles & Total & M:F & $x^{2}$ \\
\hline Aug/12 & 33 & 30 & 41 & 0 & 104 & $0.46: 1$ & $13.88^{*}$ \\
\hline Sep/12 & 201 & 179 & 21 & 89 & 490 & $1.01: 1$ & 0.00 \\
\hline Oct $/ 12$ & 157 & 128 & 8 & 0 & 293 & $1.15: 1$ & 1.51 \\
\hline Nov/12 & 172 & 62 & 68 & 4 & 306 & $1.32: 1$ & $5.84^{*}$ \\
\hline $\mathrm{Dec} / 12$ & 103 & 146 & 20 & 161 & 430 & $0.62: 1$ & $14.75^{*}$ \\
\hline $\mathrm{Jan} / 13$ & 165 & 234 & 29 & 54 & 482 & $0.63: 1$ & $22.44^{*}$ \\
\hline $\mathrm{Feb} / 13$ & 77 & 69 & 16 & 13 & 175 & $0.91: 1$ & 0.40 \\
\hline $\mathrm{Mar} / 13$ & 38 & 34 & 3 & 0 & 75 & $1.03: 1$ & 0.01 \\
\hline Apr $/ 13$ & 59 & 49 & 0 & 1 & 109 & $1.20: 1$ & 0.93 \\
\hline May/13 & 38 & 33 & 0 & 9 & 80 & $1.15: 1$ & 0.35 \\
\hline Jun/13 & 30 & 30 & 1 & 0 & 61 & $0.97: 1$ & 0.02 \\
\hline $\mathrm{Jul} / 13$ & 44 & 40 & 6 & 13 & 103 & $0.96: 1$ & 0.04 \\
\hline Total & 1117 & 1034 & 213 & 344 & 2708 & $0.90: 1$ & $7.17^{*}$ \\
\hline
\end{tabular}

Note: ${ }^{*}$ indicates a significant difference in the proportion of males and females $(\mathrm{p}<0.05)$.

Table 2. Number of specimens sampled monthly for a year, monthly sex ratio and goodness of fit analysis $\left(\chi^{2}\right)$ of Hyalella gauchensis, Palmeira das Missões, state of Rio Grande do Sul Brazil.

\begin{tabular}{cccccccc}
\hline & Males & Females & Ovigerous Females & Juveniles & Total & M:F & $\chi^{2}$ \\
\hline Aug/12 & 286 & 193 & 46 & 233 & 758 & $1.20: 1$ & $4.21^{*}$ \\
Sep/12 & 1931 & 1644 & 37 & 1515 & 5127 & $1.15: 1$ & $17.30^{*}$ \\
Oct/12 & 1476 & 1110 & 123 & 2469 & 5178 & $1.20: 1$ & $21.80^{*}$ \\
Nov/12 & 314 & 299 & 27 & 984 & 1624 & $0.96: 1$ & 0.23 \\
Dec/12 & 110 & 188 & 11 & 59 & 368 & $0.55: 1$ & $25.63^{*}$ \\
Jan/13 & 514 & 242 & 349 & 27 & 1132 & $0.87: 1$ & $5.37^{*}$ \\
Feb/13 & 761 & 844 & 283 & 111 & 1999 & $0.68: 1$ & $70.95^{*}$ \\
Mar/13 & 223 & 110 & 155 & 110 & 598 & $0.84: 1$ & 3.61 \\
Apr/13 & 342 & 185 & 226 & 222 & 975 & $0.83: 1$ & $6.32^{*}$ \\
May/13 & 135 & 173 & 72 & 63 & 443 & $0.55: 1$ & $31.84^{*}$ \\
Jun/13 & 197 & 162 & 47 & 37 & 443 & $0.94: 1$ & 0.35 \\
Jul/13 & 114 & 68 & 112 & 14 & 308 & $0.63: 1$ & $14.82^{*}$ \\
Total & 6403 & 5218 & 1488 & 5844 & 18953 & $0.95: 1$ & 7.00 \\
\hline
\end{tabular}

Note: ${ }^{*}$ indicates a significant difference in the proportion of males and females $(\mathrm{p}<0.05)$.

water reservoir. The two species were not found together at any of the collection sites.

Males and females had non-normal total distribution frequencies for both Hyalella species $(\mathrm{P}<0.05)(H$. georginae: males $\mathrm{W}=0.97$ and females $\mathrm{W}=0.95 ; H$. gauchensis: males $\mathrm{W}=0.92$ and females $\mathrm{W}=0.94$ ). Both species presented bimodal distribution. The populations were divided into groups of juveniles and adults (Figs. 1A, B) and by seasons (H.georginae Fig. 2 and H. gauchensis Fig. 3).

Hyalella georginae males had CL ranging from 0.40 $\mathrm{mm}$ to $1.61 \mathrm{~mm}$; females' CL varied from $0.37 \mathrm{~mm}$ to $1.61 \mathrm{~mm}$. For this species, males presented average $\mathrm{CL}$ $(0.89 \pm 0.22 \mathrm{~mm})$ larger than females' $(0.79 \pm 0.19 \mathrm{~mm})$ $(t=11.92, \mathrm{p}<0.05)$. Hyalella gauchensis males had CL ranging from $0.35 \mathrm{~mm}$ to $1.12 \mathrm{~mm}$; females' CL varied from $0.35 \mathrm{~mm}$ to $0.97 \mathrm{~mm}$. Males $(0.52 \pm 0.11 \mathrm{~mm})$ were significantly larger than females $(0.48 \pm 0.09 \mathrm{~mm})(t=$
$18.88, \mathrm{p}<0.05)$. Hyalella georginae males and females had average CL larger than $H$. gauchensis (males: $t=$ 87.54, females: $t=87.16$; $\mathrm{p}<0.05$ ).

Total sex-ratio for either $H$. georginae and $H$. gauchensis favored females (H. georginae 0.90:1; $\chi^{2}=$ 7.17; $\mathrm{p}<0.05$ ) (H. gauchensis 0.95: $1 ; \chi^{2}=7.00 ; \mathrm{p}<$ 0.05 ). For $H$. georginae, females were more frequent than males in August and December 2012 and in January 2013 ( $\mathrm{p}<0.05$ ) (Tab. 1). Males were more frequent than females only in November 2012 ( $\mathrm{p}<0.05$ ) (Tab. 1). For $H$. gauchensis, females were more frequent than males in most months - December 2012, January, February, Abril, May, and July 2013 ( $\mathrm{p}<0.05$ ) (Tab. 2). Males were more frequent than females only in August, September, and October $2012(\mathrm{p}<0.05)$ (Tab. 2).

For the seasonal sex-ratio analysis, $H$. georginae females were more frequent than males only in summer $\left(\chi^{2}=16.58 ; \mathrm{p}<0.05\right)$ (Fig. 4A). For H. gauchensis, females 

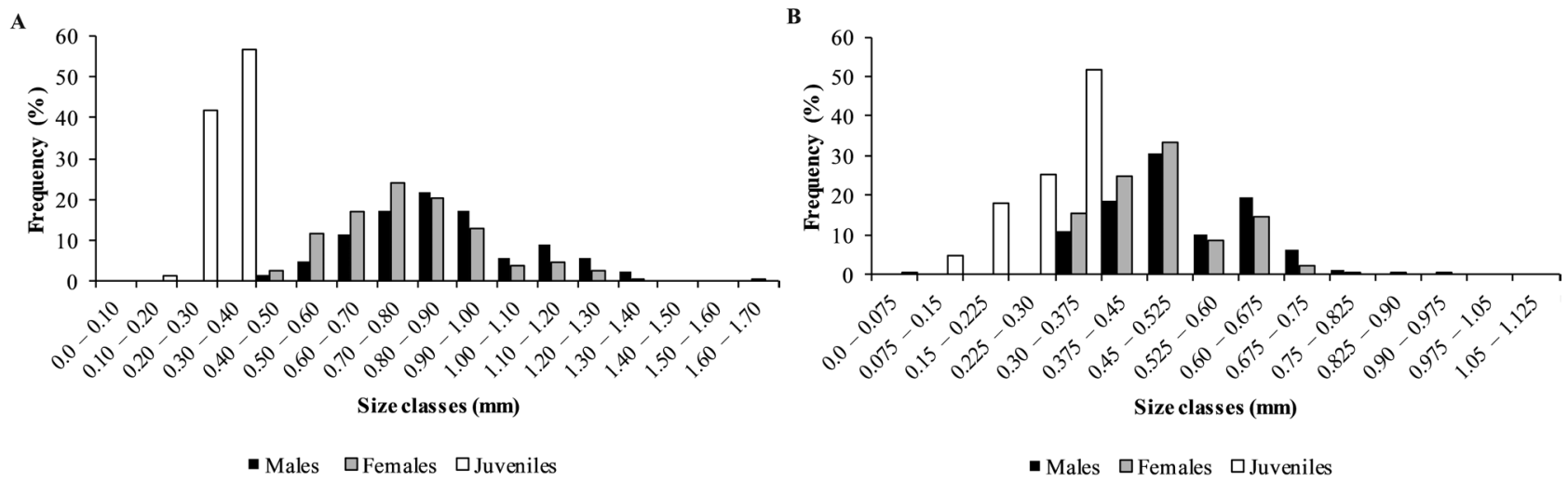

Figure 1. Size-frequency distribution of males, females and juveniles of Hyalella georginae (A) e Hyalella gauchensis (B), Palmeira das Missões, state of Rio Grande do Sul. Brazil. All sizes shown in the graph have at least one measured individual.
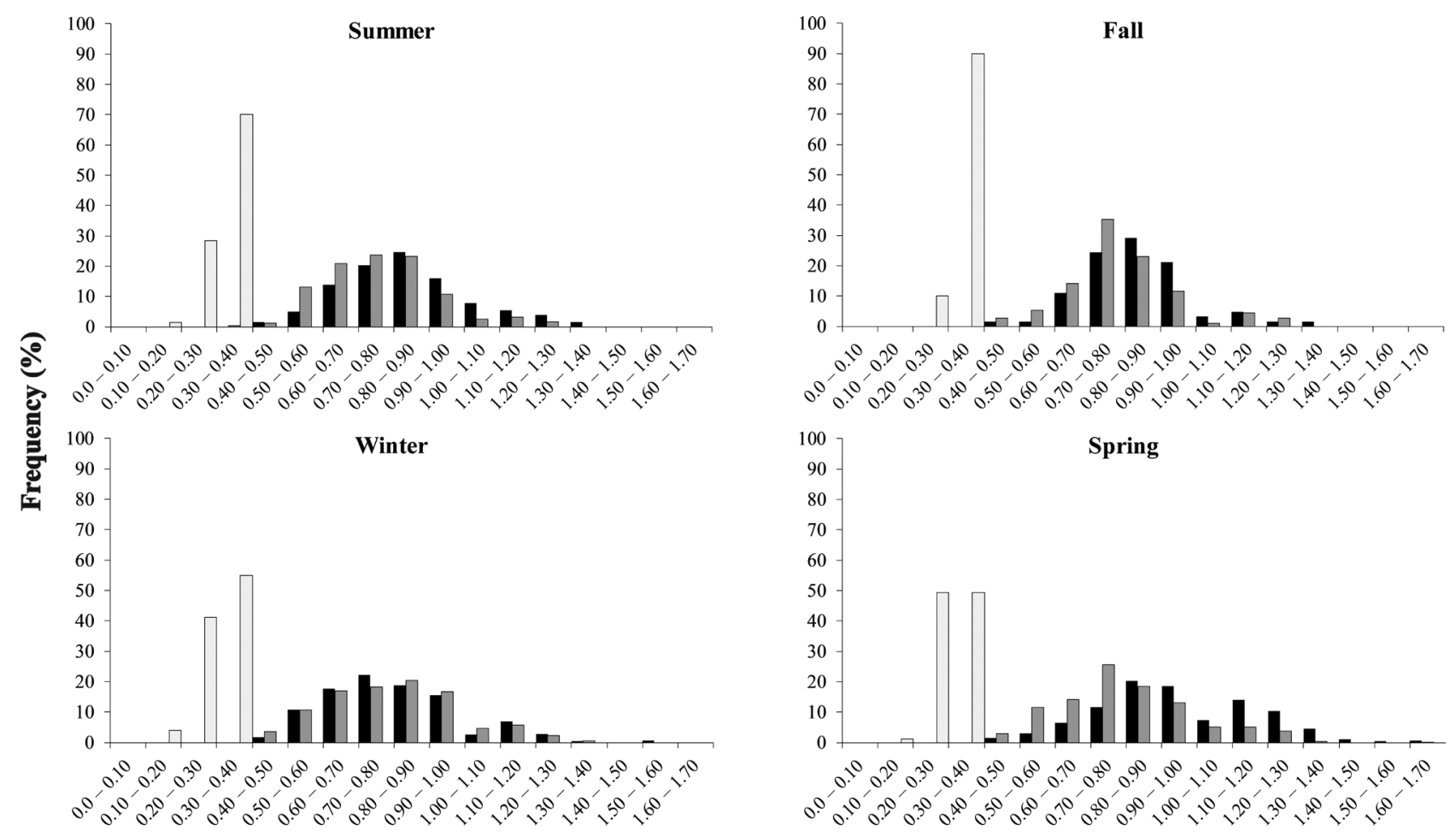

\section{Size classes $(\mathrm{mm})$}

- Males $\square$ Females $\square$ Juveniles

Figure 2. Seasonal size-frequency distribution of males, females and juveniles of Hyalella georginae, Palmeira das Missões, state of Rio Grande do Sul. Brazil. All sizes shown in the graph have at least one measured individual.

were more frequent in the fall $\left(\chi^{2}=23.70 ; \mathrm{p}<0.05\right)$ and summer $\left(\chi^{2}=67.59 ; \mathrm{p}<0.05\right)$. Males were more frequent in winter $\left(\chi^{2}=12.04 ; \mathrm{p}<0.05\right)$ and spring $\left(\chi^{2}=5.51\right.$; $\mathrm{p}<0.05$ ) (Fig. 4B). Considering the sex-ratio by size classes, females were more frequent in the intermediate size classes, and males in the upper size classes, in both species (Figs. 5A, B).
Ovigerous females of $H$. georginae were captured every month except April and May 2013 (Fig. 6). For $H$. gauchensis, ovigerous females were found across the entire year, and showed a higher frequency fluctuation throughout the year compared with H. georginae (Fig. 6). The higher reproductive intensity of $H$. georginae occurred in spring (September, $22^{\text {th }}$ to December, $21^{\text {th }}$; 

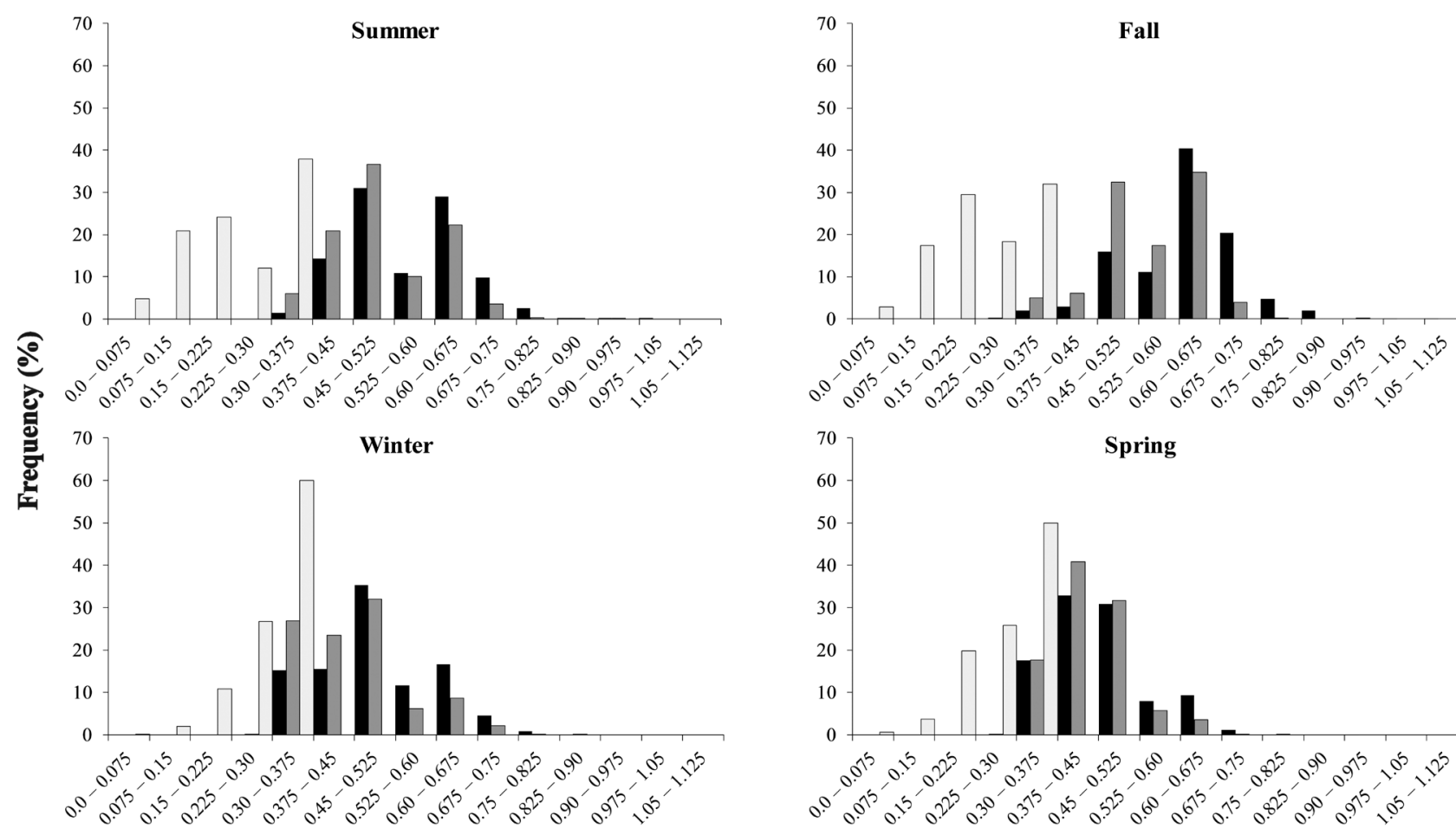

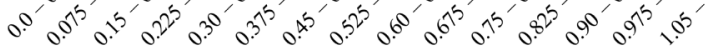

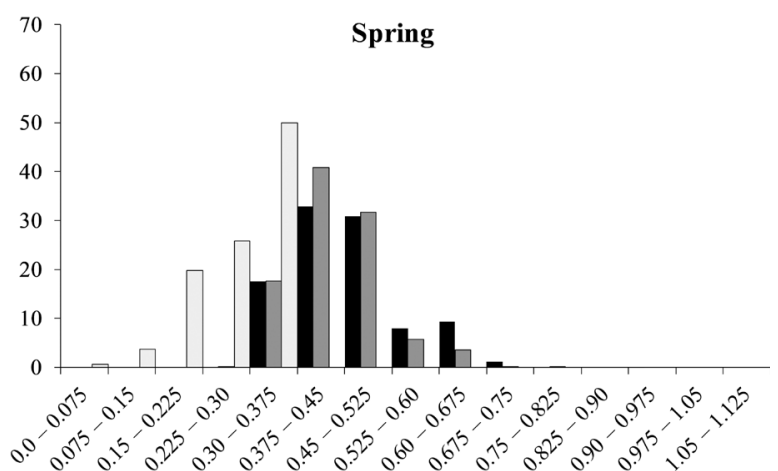

Size classes $(\mathrm{mm})$

- Males $\square$ Females $\square$ Juveniles

Figure 3. Seasonal size-frequency distribution of males, females and juveniles of Hyalella gauchensis, Palmeira das Missões, state of Rio Grande do Sul. Brazil. All sizes shown in the graph have at least one measured individual.
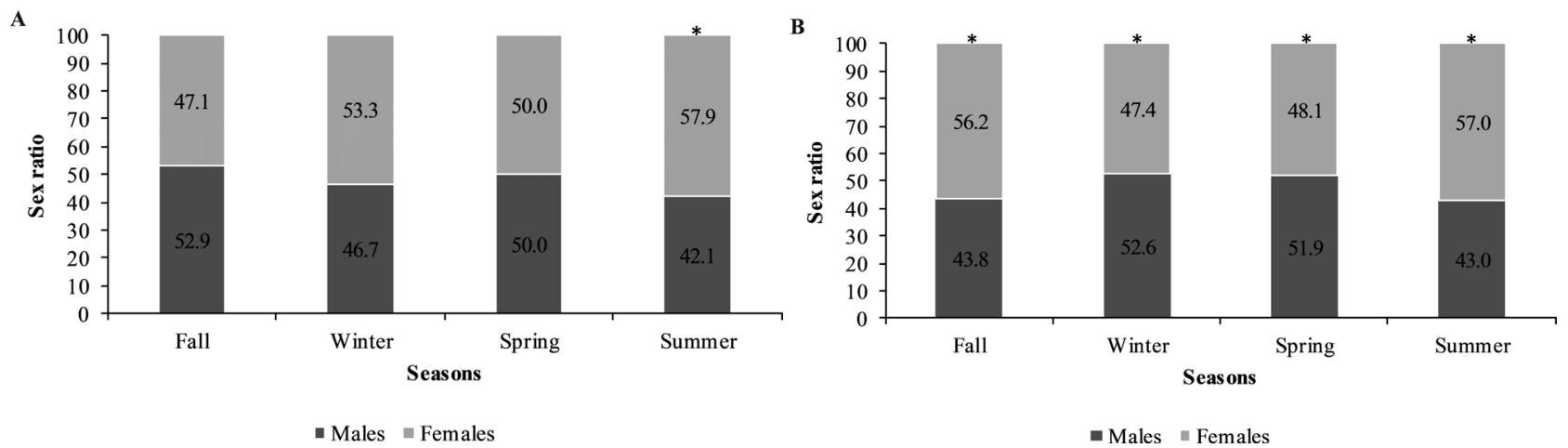

Figure 4. Seasonal sex-ratio in Hyalella georginae (A) and Hyalella gauchensis (B), Palmeira das Missões, state of Rio Grande do Sul, Brazil. Asterisks above the columns indicate significant diferences between the proportions of males and females $(p<0.05)$.

$\left.\chi^{2}=213.82 ; \mathrm{p}<0.05\right)$; for H. gauchensis, it occurred in the summer $\left(\chi^{2}=67.57\right.$; $\left.<<0.05\right)$ (Fig. 7 ).

Recruitment peaked in December 2012 for $H$. georginae, and in October 2012 for H. gauchensis (Figs. $8 \mathrm{~A}, \mathrm{~B})$. Recruitment was continuous during the seasons, with higher intensity in spring for both species (Fig. 9), when rainfall and minimum and maximum temperatures in the study area were above the climatological average of the state of Rio Grande do Sul (INMET, 2012). 

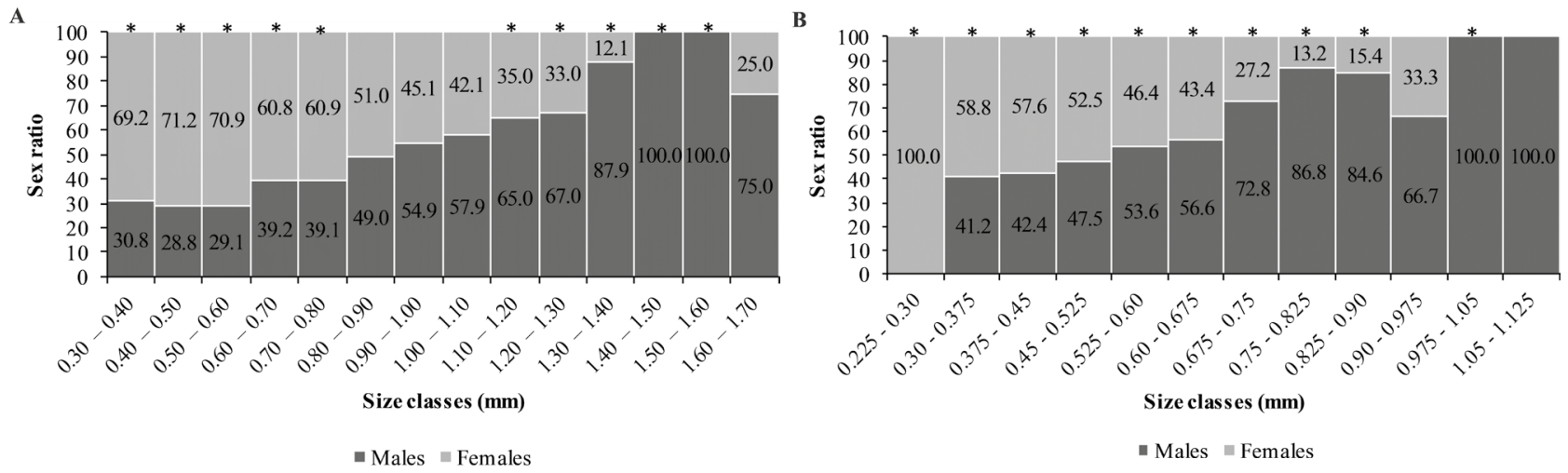

Figure 5. Sex-ratio by size classes in Hyalella georginae (A) and Hyalella gauchensis (B), Palmeira das Missões, state of Rio Grande do Sul. Brazil. Asterisks above the columns indicate significant diferences between the proportions of males and females $(\mathrm{p}<0.05)$. All sizes shown in the graph have at least one measured individual.

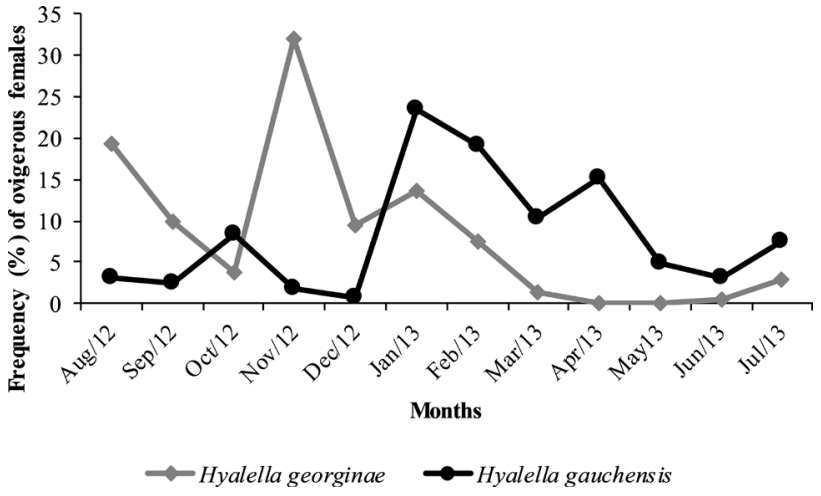

Figure 6. Frequency of ovigerou females of Hyalella georginae and Hyalella gauchensis carrying eggs or juveniles in the brood pouch along year of study, Palmeira das Missões, state of Rio Grande do Sul, Brazil.

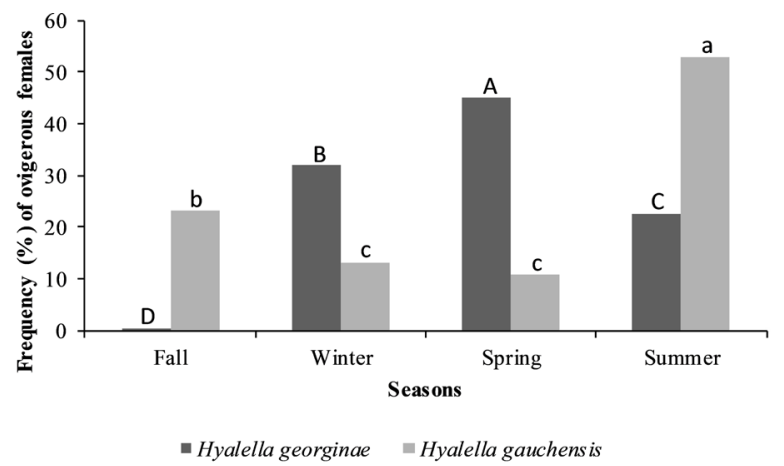

Figure 7. Frequency of ovigerous females of Hyalella georginae and Hyalella gauchensis carrying eggs or juveniles in the brood pouch along season of study, Palmeira das Missões, state of Rio Grande do Sul, Brazil. Capital letters correspond to the comparisons of the frequency of ovigerous females of Hyalella georginae among the seasons of the year and the small letters correspond to the comparisons of the frequency of ovigerous females of Hyalella gauchensis among the seasons of the year. Collumns with at least one letter in common did not differ statistically $(\mathrm{p}<0.05)$.

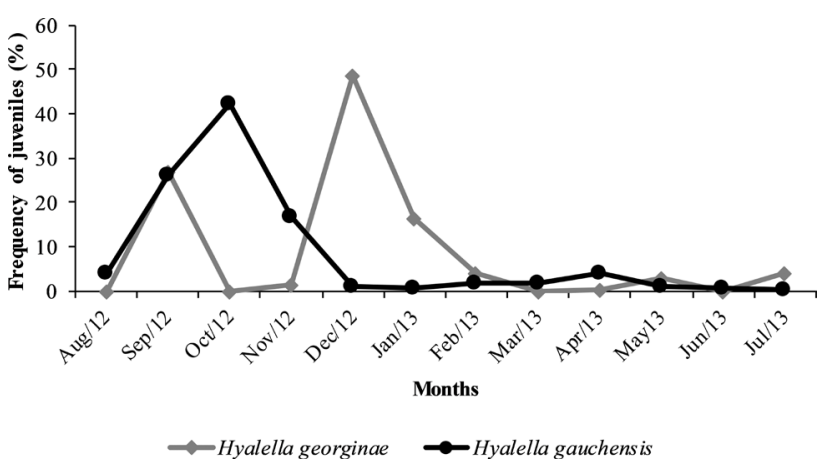

Figure 8. Relative frequency (\%) of juveniles of Hyalella georginae and Hyalella gauchensis along year study, Palmeira das Missões, state of Rio Grande do Sul, Brazil.

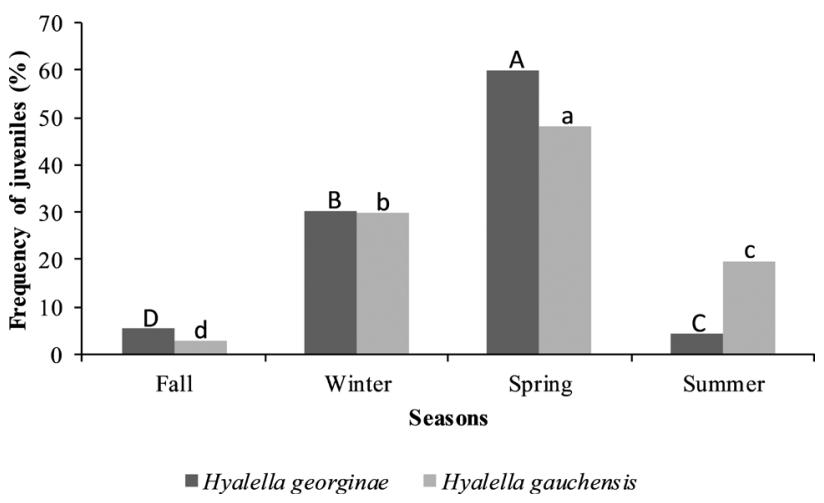

Figure 9. Relative frequency (\%) of juveniles of Hyalella georginae and Hyalella gauchensis by season of the year, Palmeira das Missões, state of Rio Grande do Sul, Brazil. Capital letters correspond to the comparisons of the frequency of juveniles of Hyalella georginae among the seasons of the year and the small letters correspond to the comparisons of the frequency of juveniles of Hyalella gauchensis among the seasons of the year. Collumns with at least one letter in common did not differ statistically $(\mathrm{p}<0.05)$. 


\section{Discussion}

In order to understand the differences in body size and abundance found in this study, life-history features and habitat characteristics may be considered, as noted by Castiglioni and Bond-Buckup (2008a) for two other Hyalella species of the "Campos de Cima da Serra" region in state of Rio Grande do Sul, Brazil. Differences between the study sites were observed and they may be related to differences in the species' life-history strategies, such as food availability and microhabitat: H. georginae was captured in the headwater sediment, while H. gauchensis was attached to macrophytes or swimming in the water column.

According to Kruschwitz (1978), small-sized individuals reach sexual maturity faster and may reproduce earlier than larger individuals, which may reflect in a population formed by large-sized individuals. Hyalella gauchensis was collected at a water reservoir susceptible to environmental perturbations caused by rainfall oscillations, which were indicated by the large numbers of specimens collected in months with warmer temperatures and lower rainfall, respectively in spring and summer (INMET, 2012). According to Boschi et al. (2011), state of Rio Grande do Sul regularly experiences periods of drought during spring and summer. During those seasons, there were increases in food availability at the study sites, reflected by large amounts of macrophytes and algae at the shelters where H. gauchensis was collected. Some species may be successful in environments subject to periodic disturbance when their populations have a high reproductive output and the progeny are of small size (Townsend et al., 2010). The water regime may influence the macroinvertebrate community structure, mainly those species that have their entire life cycle in the water, such as crustaceans (Wellborn et al., 1996).

The characteristic bimodal frequency distribution of $H$. georginae and $H$. gauchensis populations was marked by the presence of two distinct groups, juveniles and adults. This feature may be related to the seasonal reproduction and, consequently, to the recruitment peaks of the two populations. Bimodal distributions are apparently advantageous since recruitment occurs in warmer months, when food availability is higher, increasing the survival rates (Appadoo and Myers, 2004). This pattern of population frequency distribution is common to amphipod species such as Corophium multisetosum Stock, 1952 (Cunha et al., 2000), Cymadusa filosa Savigny, 1816, Mallacoota schellenbergi Ledoyer, 1984 (Appadoo and Myers, 2004), and Gammarus chevreuxi Sexton, 1913 (Subida et al., 2005).

The seasonal frequency distribution of $H$. georginae and H. gauchensis was bimodal for most seasons, and probably reflects the seasonal reproduction of both species. Castiglioni and Bond-Buckup (2008a) studying the ecological characteristics of two sympatric species of Hyalella also found bimodal size-class frequency distribution for $H$. pleocuta. The authors concluded that either the reproduction of this species is probably more intense during a few months or there is differential mortality throughout the year.

Hyalella georginae males and females had average CL larger than $H$. gauchensis and $H$. georginae and $H$. gauchensis males were significantly larger than females. The body size is considered one of the most significant ecological features and is crucial for the ecological success of the genus Hyalella (Wellborn, 2002). Male and female body sizes may vary according to latitude and environmental conditions (Panov and Macqueen, 1998; Xinqing et al., 2013) or to ecological interactions such as completion and predation (Wellborn, 2002). The larger size of males compared with females has also been reported as a sexual dimorphism in other species of Hyalella, such as H. pleocuta, H. castroi (Castiglioni and Bond-Buckup, 2008a), and H. azteca Saussure, 1858 (Geisler, 1944; Wellborn et al., 2005). Males and females often have similar growth until maturity is reached, then males grow more (Low, 1978). Females grow less due to egg production and incubation (Hartnoll, 1982) while males continue to grow during the mating period, reaching larger body sizes (Wen, 1992). During incubation, females do not molt, which also hampers them from growing at the same rate as males (Cardoso and Veloso, 1996). Besides, during the precopulatory period, males carry the females in their thorax until ovulation and fertilization (Borowsky, 1991). Smaller females are easily carried by males (Adams and Greenwood, 1983; Adams et al., 1985; Castiglioni and Bond-Buckup, 2008b), and larger males outcompete smaller ones during the mating process (Ward, 1983).

Total sex-ratio for either $H$. georginae and $H$. gauchensis favored females (Tab. 1). Amphipods may have populations with a sex-ratio of $1: 1$, or it can vary depending on the season: males may be more abundant on colder months and females in warmer months (Moore, 
1981). As it is known for amphipod populations, the sex-ratio fluctuates seasonally, and females are often more abundant than males (Cardoso and Veloso, 1996; Appadoo and Myers, 2004; Kevrekidis, 2004). The sex-ratio favoring females seen in this study probably reflects the males' behavior of choosing and guarding females, making them more susceptible to predators (Moore, 1981; Kevrekidis, 2005). A higher proportion of females was also found for H. pleocuta, H. castroi (Castiglioni and Bond-Buckup, 2008a), and H. azteca (Strong, 1972). The sex-ratio of $H$. georginae and $H$. gauchensis were different depending on the size class considered. It favored females in intermediary classes and males in the upper size classes, which characterizes an anomalous sex ratio pattern. Similar results were found by Wenner (1972) and Castiglioni and BondBuckup (2008a). The predominance of males in upper size classes is presumably influenced by the females' prolonged parental behavior, in which they carry the offspring attached to their bodies (Borowski, 1991; Thiel, 2003; Castiglioni and Bond-Buckup, 2007). Due to this behavior, females direct their energetic budget towards offspring care instead of molting; therefore, the molt is delayed, limiting the females' body size (Thiel, 2003).

For the seasonal sex-ratio analysis, $H$. georginae females were more frequent than males only in summer. For $H$. gauchensis, females were more frequent in the autumn and summer. The seasonal reproduction observed in both species of this study may be related to environmental factors of the study sites such as temperature and rainfall. Temperature is known to be an important factor influencing the life-history of aquatic invertebrates (Panov and Macqueen, 1998). Cooper (1965) and Kruschwitz (1978) reported that for H. azteca, only adult individuals survive winter, since reproduction ceases or is considerably lower then. Differently, in most studies on amphipods, reproduction is considered a continuous event, e.g., Gammarus troglophilus Hubricht and Mackin de 1940 (Jenio, 1980) and H. azteca (Alcocer et al., 2002). Besides, Castiglioni and Bond-Buckup (2008a) observed a continuous reproduction for $H$. pleoacuta and $H$. castroi, but more intense in winter and fall, respectively. Food availability (Xinqing et al., 2013) and quality (Dutra et al., 2011) influenced the reproductive capacity of individuals, causing abundance fluctuations. In those months that the temperature was higher, there was a decrease in water volume and an increase in macrophyte abundance (personal observation), providing a suitable environment for the species reproduction.

Food availability for adults and for the development of the complete life cycle may be the most important factor influencing reproduction (Sastry, 1983). In the study by Castiglioni and Bond-Buckup (2009) with H. castroi and H. pleocuta from the "Campos de Cima da Serra", fluctuations in reproductive intensities were related to macrophyte cover. Macrophytes are food and shelter for ovigerous females and juveniles and contribute for the species' reproductive success.

The continuous recruitment, with peaks in some months, was also observed in $H$. pleocuta and $H$. castroi (Castiglioni and Bond-Buckup, 2008a). The recruitment peaked in December 2012 for H. georginae, and in October 2012 for $H$. gauchensis. The hypothesis raised by the authors is that reproductive and recruitment peaks can occur in the same season. Considering the embryonic period and parental care duration, females are capable of becoming ovigerous and release the offspring within the same season. The embryonic development, from ovulation to hatching, may last 10-25 days. Hyalella pleocuta and $H$. castro $i$ have an embryonic period of approximately 12 days (Castiglioni and Bond-Buckup, 2007), and in $H$. azteca hatching can occur in 9.3-21 days (Geisler, 1944; Cooper, 1965). The parental care in Hyalella is known as the period where juveniles remain in the female's marsupium. The parental care may last roughly six days, as in $H$. pleocuta and $H$. castroi (Castiglioni and Bond-Buckup, 2007), or three days as in H. azteca (Geisler, 1944).

The population structure of $H$. georginae and $H$. gauchensis had similar features. Frequency distributions were similar, males were larger than females, the sexratio favored females, and both species showed seasonal reproduction and continuous recruitment. Those similarities and differences may be related to both species' life-history strategies, which promote adaptations to their habitat variations. The information gathered in this study about $H$. georginae and $H$. gauchensis populations may help to understand the ecological stability of these species at the studied site. Also, the results may lead to a better understanding of the species biology in the future. 


\section{ACKNOWLEDGEMENTS}

We thank to Coordenação de Aperfeiçoamento de Pessoal de Nível Superior (CAPES) and Conselho Nacional de Desenvolvimento Científico e Tecnológico (CNPq) for a fellowship to AVO and financial support to DSC (Proc. $n^{\circ} 405061 / 2015-3$ ). We are gratefull to colleagues of the Laboratório de Zoologia e Ecologia, Campus de Palmeira das Missões, Universidade Federal de Santa Maria for their assistance during field and laboratory activities. This study was carried out according to state and federal laws concerning wildanimal sampling.

\section{References}

Adams, J. and Greenwood, P.J. 1983. Why are males bigger than females in pre-copula pairs of Gammarus pulex? Behavioral Ecology and Sociobiology, 13: 239-241.

Adams, W.J.; Kimerle, R.A. and Mosher, R.G. 1985. Aquatic safety assessment of chemicals sorbed to sediments. p. 429453. In: R.D. Cardwell; R. Purdy and R.C. Bahner (ed), Aquatic Toxicology and Hazard Assessment: $7^{\text {th }}$ Symposhium. Philadelphia, American Society for Testing and Materials.

Alcocer, R.J.; Escobar, E. and Peralta, L. 2002. Population structure of the macrobenthic amphipod H. azteca Sausurre (Crustacea: Peracarida) on the littoral zone of six crater lakes. p. 111-115. In: E. Escobar-Briones and F. Alvarez (ed), Modern Approaches to the Study of Crustacea. New York, Kluwer Academic/Plenum Publishers.

Appadoo, C. and Myers, A.A. 2004. Reproductive bionomics and life history traits of three gammaridean amphipods, Cymadusa filosa Savigny, Ampithoe laxipodus Appadoo and Myers and Mallacoota schellenbergi Ledoyer from tropical Indian Ocean (Mauritius). Acta Oecologica, 26: 227-238.

Baldinger, A.J. 2004. A new species of Hyalella (Crustacea, Amphipoda, Hyalellidae) from Ash Springs, Lincoln Country, USA, with a key to the species of the genus in North America and the Caribbean region. Journal of Natural History, 38: 1087-1096.

Bastos-Pereira, R. and Bueno, A.A.P. 2013. A new species of freshwater amphipod (Dogielinotidae, Hyalella) from Southeastern Brazil. Nauplius, 21: 79-87.

Bastos-Pereira, R; Oliveira, M.P.A. and Ferreira, R.L. 2018. Anophtalmic and epigean? Description of an intriguing new species of Hyalella (Amhipoda, Hyalellidae) from Brazil. Zootaxa, 4407(2): 254-266.

Borowsky, B. 1991. Patterns of reproduction of some amphipod crustaceans and insights into the nature of their stimuli.p.33-39. In: R.T. Bauer and W. Martin (ed), Crustacean Sexual Biology. New York, Columbia University Press.

Boschi, R.; Oliveira, S.R.M. and Assad, E.D. 2011. Técnicas de mineração de dados para análise da precipitação pluvial decenal no Rio Grande do Sul. Revista Engenharia Agrícola, 31: 11891201.
Bousfield, E.L. 1996. A contribution to the reclassification of Neotropical freshwater hyalellid amphipods (Crustacea: Gammaridea, Talitroidea). Bolletino del Museo Civico di Storia Naturale de Verona, 20: 175-224.

Bueno, A.A.P.; Araujo, P.B.; Cardoso, G.M.; Gomes, K.M. and BondBuckup, G. 2013. Two new species of Hyalella (Amphipoda, Dogielinotidae) from Brazil. Crustaceana, 86: 802-819.

Bueno, A.A.P.; Rodrigues, S.G. and Araujo, P.B. 2014. O estado da arte do gênero Hyalella Smith, 1874 (Crustacea, Amphipoda, Senticaudata, Hyalellidae) no Brasil. p. 57-88. In: C. Hayashi (ed), Tópicos de Atualização em Ciências Aquáticas, vol. 1. Uberaba, UFTM.

Cardoso, R.S. and. Veloso, V.G. 1996. Population biology and secondary production of the sandhopper Pseudorchestoidea brasiliensis (Amphipoda: Talitridae) at Prainha Beach, Brazil. Marine Ecology Progress Series, 142: 111-119.

Cardoso, G.M.; Bueno, A.A.P. and Ferreira, R.L. 2011. A new troglobiotic species of Hyalella (Crustacea, Amphipoda, Dogielinotidae) from Southeastern Brazil. Nauplius, 19: 17-26.

Cardoso, G.M.; Araujo, P.B.; Bueno, A.A.P. and Ferreira, R.L. 2014. Two new subterranean species of Hyalella Smith, 1874 (Crustacea: Amphipoda: Hyalellidae) from Brazil. Zootaxa, 3814: 253-348.

Casset, M.A.; Momo, F.R. and Giorgio, A.D.N. 2011. Dinámica poblacional de dos especies de anfipodos y su relación con la vegetación acuática en un microambiente de la cuenca del río Luján, Argentina. Ecologia Austral, 11: 79-85.

Castiglioni, D.S. and Bond-Buckup, G. 2007. Reproductive strategies of two sympatric species of Hyalella Smith, 1874 (Amphipoda, Dogielinotidae) in laboratory conditions. Journal of Natural History, 41: 1571-1584.

Castiglioni, D.S. and Bond-Buckup, G. 2008a. Ecological traits of two sympatric species of Hyalella Smith, 1874 (Crustacea, Amphipoda, Doglielinotidae) from southern Brazil. Acta Oecologica, 33: 36-48.

Castiglioni, D.S. and Bond-Buckup, G. 2008b. Pairing and reproductive success in two sympatric species of Hyalella (Crustacea, Amphipoda, Doglielinotidae) from southern Brazil. Acta Oecologica, 33: 49-55.

Castiglioni, D.S. and Bond-Buckup, G. 2009. Egg production of two sympatric species of Hyalella Smith, 1874 (Crustacea, Amphipoda, Dogielinotidae) in aquaculture ponds in southern Brazil. Journal of Natural History, 43: 1273-1289.

Castiglioni, D.S.; Ozga, A.V.; Rodrigues, S. G. and Bueno, A.A.P. 2016. Population dynamics of a freshwater amphipod from South America (Crustacea, Amphipoda, Hyalellidae). Nauplius, 24: e2016028.

Colla, M.F. and César, I.I. 2015. A new species of Hyalella (Crustacea, Amphipoda, Dogielinotidae) from the Atlantic Forest of Missiones, Argentina. Zookeys, 481: 25-38.

Cooper, W.E. 1965. Dynamics and production of a natural population of a freshwater amphipod Hyalella azteca. Ecological Monographs, 35: 377-394.

Cunha, M.R.; Sorbe, J.C. and Moreira, M.H. 2000. The amphipod Corophium multisetosum (Corophiidae) in Ria de Aveiro (NW Portugal). I. Life history and aspects of reproductive biology. Marine Biology, 137: 637-650. 
Curi, P.R. and Moraes, R.V. 1981. Associação, homogeneidade e contrastes entre proporções em tabelas contendo distribuições multinomiais. Ciência e Cultura, 33: 712-722.

Duan, Y.; Guttma, S.I. and Oris, J.T. 1997. Genetic differentiation among laboratory populations of Hyalella azteca: implications for toxicology. Environmental Toxicology and Chemistry, 16: 691-695.

Dutra, B.K.; Fernandes, F.A.; Failace, D.M. and Oliveira, G.T. 2011. Effect of roundup (glyphosate formulation) in the energy metabolism and reproductive traits of Hyalella castroi (Crustacea, Amphipoda, Dogielinotidae). Ecotoxicology, 20: 255-263.

Geisler, S.S.J. 1944. Studies on the postembryonic development of Hyalella azteca (Saussure). Biological Bulletin, 86: 6-22.

González, E.R. and Watling, L. 2002a. A new species of Hyalella from the Andes in Peru (Crustacea: Hyalellidae). Revista de Biología Tropical, 50: 649-658.

González, E.R. and Watling, L. 2002b. Redescription of Hyalella azteca from its type locality, Vera Cruz, Mexico (Amphipoda: Hyalellidae). Journal of Crustacean Biology, 22: 173-183.

González, E.R. and Watling, L. 2003a. A new species of Hyalella from the Patagonia, Chile, with the redescription of H. simplex Schellenberg, 1943 (Crustacea: Amphipoda). Journal of Natural History, 37: 2077-2094.

González, E.R. and Watling, L. 2003b. A new species of Hyalella from Brazil (Crustacea: Amphipoda), and redescriptions of three other species in the genus. Journal of Natural History, 37: 2045-2076.

González, E.R.; Bond-Buckup, G. and Araujo, P.B. 2006. Two new species of Hyalella from southern Brazil (Amphipoda: Hyalellidae) with a taxonomic key. Journal of Crustacean Biology, 26: 355-365.

Grosso, L. and Peralta, M. 1999. Anfípodos de agua dulce sudamericanos. Revisión del género Hyalella Smith. Acta Zoologica Lilloana, 45: 79-98.

Guerao, G. 2003. Some observations on the life history of the freshwater amphipod Echinogammarus longisetosus Pinkster, 1973 (Gammaridea) from Catalonia (Spain, N Iberia peninsula). Animal Biodiversity and Conservation, 26: 31-39.

Hartnoll, R.G. 1982. Growth.p. 111-196. In: L.G. Abele (ed), The Biology of Crustacea, vol. 2. Embryology, morphology and genetics. New York, Academic Press.

Hutchinson, G.E. 1981. Introducción a la ecologia de pobliaciones. Barcelona, Editora Blume, 492p.

IBGE, Instituto Brasileiro de Geografia e Estatística. 2014. Avaliable in http://www.ibge.gov.br. Accessed in June, 2014.

INMET, Instituto Nacional de Meteorologia, Brasília, Distrito Federal, Brasil. 2012. Avaliable in http://www.inmet.gov.br. Accessed in October, 2013.

Jenio, F. 1980. The life cycle and ecology of Gammarus troglophilus Hubricht and Mackin. Crustaceana, 6: 204-215.

Kevrekidis, T.2004. Population dynamics, growth and reproduction of Corophium insidiosum (Crustacea: Amphipoda) at low salinities in Monolimni lagoon (Evros Delta, north Aegean Sea). Hydrobiologia, 522: 117-132.

Kevrekidis, T. 2005. Life history, aspects of reproductive biology and production of Corophium orientale (Crustacea: Amphipoda) in Monolimni lagoon (Evros Delta, north Aegean Sea). Hydrobiologia, 537: 53-70.
Kruschwitz, L.G. 1978. Environmental factors controlling reproduction of the amphipod Hyalella azteca. Proceedings of the Oklahoma Academy of Science, 58: 16-21.

Low, B.S. 1978. Environnmental uncertainty and parental strategies of marsupials and placentals. American Naturalist, 112:319-335.

Markus, R. 1971. Elementos de estatística aplicada. Porto Alegre, Faculdade de Agronomia e Veterinária da UFRGS: Centro Acadêmico Leopoldo Cortez, 329p.

Moore, P.G. 1981. The life histories of the amphipods Lembos websteri Bate and Corophium bonnellii Milne Edwards in kelp holdfasts. Journal of Experimental Marine Biology and Ecology, 49: $1-50$.

Muskó, I.B. 1992. Life history of Corophium curvispinum G. O. Sars (Crustacea, Amphipoda) living on macrophytes in Lake Balaton. Hydrobiologia, 243/244: 197-202.

Ozga, A.V. and Castiglioni, D.S. 2017. Reproductive biology of two species of Hyalella Smith, 1874 (Crustacea: Amphipoda: Hyalellidae) from southern Brazil. Journal of Natural History, 51:2509-2521.

Panov, V.E. and Macqueen, D.J. 1998. Effects of temperature on individual growth rate and body size of a freshwater amphipod. Canadian Journal of Zoology, 76: 1107-1116.

Peel, M.C.; Finlayson, B.L. and Mcmahon, T.A. 2007. Updated world map of the Köppen-Geiger climate classification. Hydrology and Earth System Sciences Discussions, European Geosciences Union, 11: 1633-1644.

Pereira, V.F.G.C. 2004. Hyalella dielaii sp. nov. from São Paulo Brazil (Amphipoda, Hyalellidae). Revista brasileira de Zoologia, 21: 179-184.

Rodrigues, S.G.; Bueno, A.A.P. and Ferreira, R.L. 2014. A new troglobiotic species of Hyalella (Crustacea, Amphipoda, Hyalellidae) with a taxonomic key for the Brazilian species. Zootaxa, 3815: 200-214.

Santos, S.; Negreiros-Fransozo, M.L. and Fransozo, A. 1995. Estructura poblacional de Portunus spinimanus Latreille, 1819 (Crustacea, Brachyura, Portunidae) en la Enseada de la Fortaleza, Ubatuba (SP). Revista de Investigaciones Marinas, 16: 37-43.

Sastry, A.N. 1983. Ecological aspects of reproduction. p. 179-270. In: F.J. Vernberg and W.B. Vernberg (eds), The Biology of Crustacea, vol. 8: Enviromental adaptations. Academic Press, New York, 383p.

Streck, M.T.; Monticelli, G.; Rodrigues, S.G.; Graichen, D.A.S. and Castiglioni, D.S. 2017. Two new species of Hyalella (Crustacea, Amphipoda, Hyalellidae) from state of Rio Grande do Sul, Southern Brazil. Zootaxa, 4337: 263-278.

Strong, Jr. D.R. 1972. Life history variation among populations of an amphipod (Hyalella azteca). Ecology, 53: 1103-1111.

Subida, M.D.; Cunha, M.R. and Moreira, M.H. 2005. Life history, reproduction, and production of Gammarus chevreuxi (Amphipoda: Gammaridae) in the Ria de Aveiro, northwestern Portugal. Journal of the North American Benthological Society, 4: 82-100.

Thiel, M. 2003. Extended parental care in crustaceans - an update. Revista Chilena de História Natural, 76: 205-218.

Townsend, C.R.; Begon, M. and Harper, J.L. 2010. Fundamentos em ecologia. Porto Alegre, Editora Artmed, 576p.

Vainola, R.; Witt,J.D.S.; Grabowski, M.; Bradbury,J.H.; Jazdzewski, K. and Sket, B. 2008. Global diversity of amphipods (Amphipoda; Crustacea) in freshwater. Hydrobiologia, 595: 241-255. 
Ward, P.I. 1983. Advantages and a disadvantage of large size for male Gammarus pulex (Crustacea: Amphipoda). Behavioral Ecology and Sociobiology, 14: 69-76.

Wellborn, G.A. 1994. Size-biased predation and prey life histories: a comparative study of freshwater amphipod populations. Ecology, 75: 2104-2117.

Wellborn, G.A. 1995. Determinants of reproductive success in freshwater amphipod species that experience different mortality regimes. Animal Behavior, 50: 353-363.

Wellborn, G.A.; Skelly, D.K. and Werner, E.E. 1996. Mechanisms creating community structure across a freshwater habitat gradient. Annual Review of Ecology and Systematics, 27: $337-$ 363.

Wellborn, G.A. 2002. Trade-off between competitive ability and antipredator adaptation in a freshwater amphipod species complex. Ecology, 83: 129-136.

Wellborn G.A.; Cothran, R. and Bartholf, S. 2005. Life history and allozyme diversification in regional ecomorphs of the Hyalella azteca (Crustacea: Amphipoda) species complex. Biological Journal of the Linnean Society, 84: 161-175.

Wen, Y.H. 1992. Life history and production of Hyalella azteca

(Crustacea, Amphipoda) in a hypereutrophic prairie pond in southern Alberta. Canadian Journal of Zoology, 70: 1417-1424.

Wenner, A.M. 1972. Sex-ratio as a function of size in marine Crustacea. American Midland Naturalist, 106: 321-350.

Witt, J.D.S. and Hebert, P.D.N. 2000. Cryptic species diversity and evolution in the amphipod genus Hyalella within central glaciated North America: a molecular phylogenetic approach. Canadian Journal of Fisheries and Aquatic Sciences, 57: 687-698.

Xinqing, Z.; Lingfeng, H.; Bangqin, H. and Yongqing, L.I.N. 2013. Factores regulating population dynamics of the amphipod Ampithoe valida in a eutrophic subtropical coastal lagoon. Acta Oceanologica Sinica, 32: 56-65.

Zar, J.H. 1996. Biostatistical analysis. Upper Saddle River, Prentice Hall. 941p. 